\title{
Vulnerability and adaptation to climate-related fire impacts in rural and urban interior Alaska
}

\author{
Sarah F. Trainor, ${ }^{1}$ Monika Calef, ${ }^{2}$ David Natcher, ${ }^{3}$ F. Stuart Chapin III, ${ }^{4}$ A. David McGuire, ${ }^{5}$ \\ Orville Huntington, ${ }^{6}$ Paul Duffy, ${ }^{7}$ T. Scott Rupp, ${ }^{7}$ La'Ona DeWilde, ${ }^{4}$ Mary Kwart, ${ }^{8}$ Nancy Fresco ${ }^{7}$ \& \\ Amy Lauren Lovecraft ${ }^{9}$ \\ 1 Institute of Northern Engineering, University of Alaska Fairbanks, P.O. Box 755960, Fairbanks, AK 99775-5960, USA \\ 2 Department of Geography and Planning, University at Albany, State University of New York, 1400 Washington Ave., Albany, NY 12222, USA \\ 3 Department of Bioresource Policy, Business and Economics, University of Saskatchewan, 51 Campus Drive, Saskatchewan S7N 5A8, Canada \\ 4 Institute of Arctic Biology, University of Alaska Fairbanks, P.O. Box 757000, Fairbanks, AK 99775-7000, USA \\ 5 Alaska Cooperative Fish and Wildlife Research Unit, University of Alaska Fairbanks, Fairbanks, 209 Irving 1, P.O. Box 757020, AK 99775-7020, USA \\ 6 Alaska Native Science Commission, 3211 Providence Drive, Anchorage, AK 99508, USA \\ 7 School of Natural Resource and Agricultural Sciences, University of Alaska Fairbanks, P.O. Box 757140, Fairbanks, AK 99775, USA \\ 87014 Fairweather Park Loop, Anchorage, AK 99518, USA \\ 9 Department of Political Science, University of Alaska Fairbanks, P.O. Box 756420, AK 99775-6420, USA
}

\section{Keywords}

Climate change; interior Alaska; rural; urban; vulnerability; wildfire.

\section{Correspondence}

Sarah F. Trainor, Institute of Northern

Engineering, University of Alaska Fairbanks,

P.O. Box 755960, Fairbanks, AK 99775-5960,

USA. E-mail: fnsft@uaf.edu

doi:10.1111/j.1751-8369.2009.00101.x

\begin{abstract}
This paper explores whether fundamental differences exist between urban and rural vulnerability to climate-induced changes in the fire regime of interior Alaska. We further examine how communities and fire managers have responded to these changes and what additional adaptations could be put in place. We engage a variety of social science methods, including demographic analysis, semi-structured interviews, surveys, workshops and observations of public meetings. This work is part of an interdisciplinary study of feedback and interactions between climate, vegetation, fire and human components of the Boreal forest social-ecological system of interior Alaska. We have learned that although urban and rural communities in interior Alaska face similar increased exposure to wildfire as a result of climate change, important differences exist in their sensitivity to these biophysical, climate-induced changes. In particular, reliance on wild foods, delayed suppression response, financial resources and institutional connections vary between urban and rural communities. These differences depend largely on social, economic and institutional factors, and are not necessarily related to biophysical climate impacts per se. Fire management and suppression action motivated by political, economic or other pressures can serve as unintentional or indirect adaptation to climate change. However, this indirect response alone may not sufficiently reduce vulnerability to a changing fire regime. More deliberate and strategic responses may be required, given the magnitude of the expected climate change and the likelihood of an intensification of the fire regime in interior Alaska.
\end{abstract}

Recent biophysical and climate research has linked climate change with wildfire activity (Duffy et al. 2005; Westerling et al. 2006). Similarly, social science research has examined human attitudes, perceptions of and response to wildfire risk (Gardner et al. 1987; Brunson \& Shindler 2004; Kneeshaw et al. 2004; Steelman \& Kunkel 2004; Field \& Jensen 2005; Huntington \& Huntington 2005), and recent work has applied the natural-hazards framework to wildfire risk analysis (McCaffrey 2004).
However, few studies bring the biophysical and social analyses together in an interdisciplinary investigation of the social-ecological system of climate change, wildfire and human vulnerability (Calef et al. 2008).

The Alaskan wildfire seasons of 2004 and 2005 were two of the three most extensive in the 57-year historical record (1950-2007). During the record-breaking 2004 season, 2608256 ha burned state-wide, threatening 20 different communities, including one Fairbanks 
subdivision that was evacuated several times. The area burned in 2005 was the third largest on record, at 1907021 ha. The average annual total area burned (1950-2007) is 370294 ha, yet there is high interannual variability ( \pm 562826 ha, SD). During the 2004 fire season, the air quality in Fairbanks exceeded the US Environmental Protection Agency's highest danger rating of "hazardous" (over $250 \mu \mathrm{g} \mathrm{m}^{-3}$ for a 24 -h average) for a total of 15 days (AMQA 2004). With the impacts of climate change amplified in northern latitudes, warmer temperatures and drier fuels are expected to increase the frequency of extreme fire seasons across most of the North American Boreal forest (Duffy et al. 2005; Flannigan et al. 2005; Symon et al. 2005; Flannigan et al. 2006; Kasischke et al. 2006). Under changing climate conditions, the average area burned per year in Alaska is projected to double by the middle of this century (Balshi et al. 2008). By the end of this century, fire is projected to triple in Alaska under a moderate greenhouse gas emissions scenario, and to quadruple under a high emissions scenario.

From the perspective of human dimensions of global change, it is important to understand how a changing fire regime will impact urban and rural communities in Alaska, and to consider how communities can respond proactively, rather than be disadvantaged by projected changes in the fire regime. This will provide essential information to managers and decision makers in planning, preparing, and focusing resources for adaptation and response to climate change. We employ an interdisciplinary approach to assess the vulnerability of urban and rural communities in interior Alaska to climaterelated fire impacts, by comparing the constituent parts of vulnerability: exposure, sensitivity and adaptive capacity. Our results underscore the variable vulnerabilities of different populations to climate change, and highlight how this variability is influenced by public perception and institutional barriers.

\section{Background and conceptual approach}

Wildfire in Alaska occurs primarily in the interior Boreal forest, north of the Alaska Range and south of the Brooks Range (Fig. 1). These forests are composed of early successional birch and aspen and late successional, highly flammable black spruce and white spruce, with typical fire-return intervals of 50 to 200 years (Fastie et al. 2002). Fire is the dominant ecological disturbance in Alaska's Boreal forest, and plays an important ecological role in nutrient cycling and moisture availability (Chapin et al. 2006). In addition, the fire-initiated succession from dark, absorptive spruce to light, reflective deciduous forest is

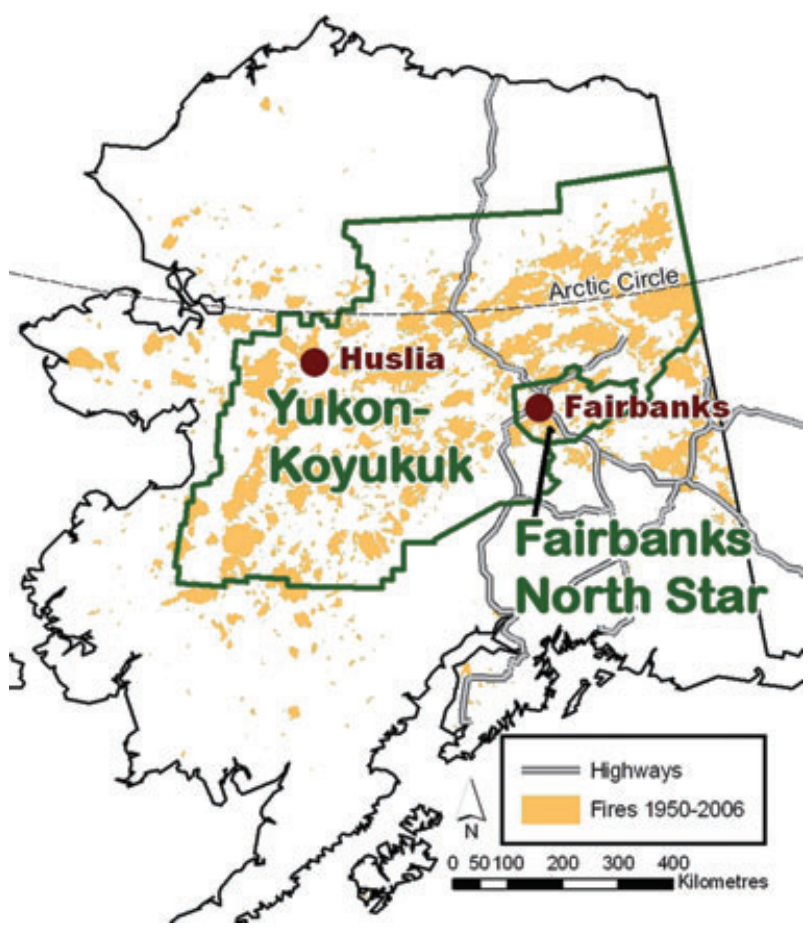

Fig. 1 Map of wildfire perimeters, 1950-2006, showing Fairbanks North Star Borough (FNSB) and Yukon-Koyukuk Census District (YKCD), the locations of the City of Fairbanks and Huslia, and the Alaska road network.

one of the few regional negative feedback mechanisms to climate warming (Chapin et al. 2000; Randerson et al. 2006).

In contrast to their counterparts in the lower 48 states, fire suppression agencies and fire managers in Alaska have historically had neither the financial nor the labour resources necessary to implement a full fire suppression policy. As a result, an innovative fire management policy has evolved in Alaska that focuses suppression resources on population centres and areas of high value at risk (Todd \& Jewkes 2006; Calef et al. 2008). In unpopulated areas with low-value areas at risk, fires are monitored, and suppression action is limited.

The developing field of climate change vulnerability studies has its roots in the arenas of natural hazards, food security and climate change (Kelly \& Adger 2000). Our analysis builds on the concepts of vulnerability and adaptation as they are established and used by the Intergovernmental Panel on Climate Change (IPCC), modified to include the larger social-ecological system and nonclimate stressors (Box 1). We include a consideration of non-climate stressors because institutional, economic, social and cultural conditions are important determinants of vulnerability and adaptive capacity (Adger \& Kelly 1999; Kelly \& Adger 2000; Turner, Kasperson et al. 2003; O’Brien, Leichenko et al. 2004; O’Brien, Sygna et al. 
2004). These definitions represent a scientific consensus developed over several years of research and collaboration. They are specific to and have been developed in the context of climate change and variation, yet are conceptually well corroborated in an external, long-standing tradition of risk-and-natural-hazards literature (Turner, Kasperson et al. 2003; Fussel \& Klein 2006; IPCC 2007). In this paper we explicitly consider the coupled socialecological system, including feedback and interactions among climate, vegetation, fire regime, fire policy and communities, with special attention paid to the interactions between and among global, national, regional and local scales (Fig. 2) (Berkes \& Folke 1998; Chapin et al. 2003; Turner, Kasperson et al. 2003; Calef et al. 2008).

Box 1. Definitions of concepts based on those of the Intergovernmental Panel on Climate Change (IPCC 2007) and Fussel \& Klein (2006), and modified to include the social-ecological system and non-climate stressors

Vulnerability is the degree to which a system is susceptible to, or unable to cope with, adverse effects of climate change and non-climate stressors ... Vulnerability is a function of the character, magnitude and rate of climate change ... or non-climate stressors to which a system is exposed, its sensitivity and its adaptive capacity (modified from IPCC 2007). In short, $V=\mathrm{fn}(E, S, A C)$, where $V$ is vulnerability, $E$ is exposure, $S$ is sensitivity and $A C$ is adaptive capacity.

Exposure is the nature and degree to which a system is exposed to a biophysical hazard or stressor, and related economic and social stressors (modified from Fussel \& Klein 2006).

Sensitivity is the degree to which a system is affected, either adversely or beneficially, by climate-related or other stimuli (modified from Fussel \& Klein 2006).

Adaptation is adjustments in coupled socialecological systems in response to actual orexpected climatic or non-climatic stimuli, or their effects, which moderate harm or exploit beneficial opportunities (modified from Fussel \& Klein 2006).

Adaptive capacity is the ability of a system to adjust to climatic or non-climatic change, to moderate potential damage, to take advantage of opportunities, or to cope with the consequences (modified from IPCC 2007).

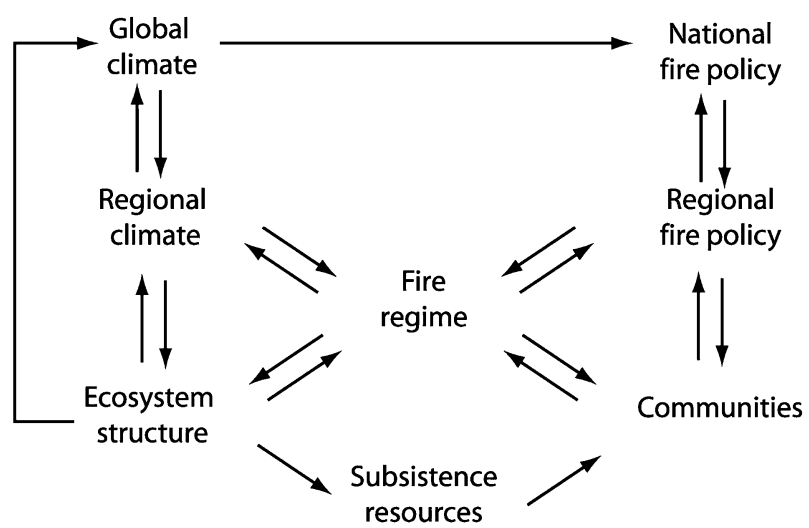

Fig. 2 Conceptual model of the interactions among climate, ecosystems, fire, human communities and fire policy in the Alaskan Boreal forest (from Chapin et al. 2008).

Over the past decade, there have been a number of efforts to outline a framework for vulnerability assessment, and to characterize vulnerability and its related constituents, adaptive capacity and adaptation in relation to environmental change, and climate change in particular (Adger \& Kelly 1999; Smit et al. 2000; Turner, Kasperson et al. 2003; Ford \& Smit 2004; Keskitalo 2004; Luers 2005; Schroter et al. 2005). We conceptualize vulnerability as the function of exposure, sensitivity and the dynamic capacity of the system to adapt to change (Box 1).

Adaptive capacity has been defined as the means by which a community can adapt to the social and natural environment, as well as to actively modify it (Berkes $\&$ Folke 1994; Hanna et al. 1996; Holling et al. 1998). Consistent with the definition employed by Honigman (1983: $150)$, adaptive capacity is a process whereby communities act to seize opportunities and resources available in both the social and physical environments. It is the problem solving mechanisms in human behaviour that facilitates a dynamic approach to environmental interaction. The term "adaptive capital" has also been used to describe this capacity, but as Berkes \& Folke (1994) have noted, the use of adaptive capital fails to adequately describe a group's potential to not only adapt to, but also actively modify, its social and ecological setting. Adaptive capacity also includes the locally evolved knowledge base used by community members, and the worldview and ethics that underpin a community's social structure (Holling et al. 1998: 349). Thus, the concept of adaptive capacity extends beyond the biological realm to include behaviour that is subject to interpretation by cultural values, including a judgmental dimension, in addition to the survival or needs-satisfying functions (Bennett 1996). This includes qualities that can be found in operation in any dimension, 
including: demography, social organization, economy, technology and cultural values.

Polsky et al. (2007) noted that the process of vulnerability assessment is iterative, not linear. They outlined a framework for vulnerability analysis that they call the vulnerability scoping diagram, which can be utilized for case-study comparisons, even when measured and qualitative parameters vary.

Complete vulnerability assessments covering a range of steps including modelling, measuring indicators and operationalizing, as outlined by Turner, Kasperson et al. (2003) and Schroter et al. (2005), are difficult to accomplish by a single research team working within the confines of a typical funding cycle, and must be adapted to suit the particular project and system in question (Turner, Matson et al. 2003).

Nelson et al. (2007) describe the benefits of conceptualizing and analysing adaptation and adaptive capacity within a resilience framework, noting the ways in which adaptation measures may provide immediate risk reduction, yet reduce overall system resilience in the longer term. They argue that it is therefore, "incumbent on decision-makers and citizens to outline acceptable levels of vulnerability, who will be vulnerable, and to what type of events" (Nelson et al. 2007: 408). They highlight the significance of "management abilities and the role of governance and institutions" (Nelson et al. 2007: 408) in increasing resilience and decreasing vulnerability, and underscore the importance of institutional structure and function in resilience to environmental change (Dietz et al. 2003).

Keskitalo suggests that vulnerability is "a composite concept, incorporating environmental, social, economic, political, cultural and psychological factors" (Keskitalo 2004: 429). She advocates an "extended stakeholder analysis" incorporating: stakeholder perceptions; institutional structures, communications and cross-scale interactions; and qualitative, ethnographic data collection and analysis (Keskitalo 2004: 431).

Turner, Matson et al. (2003) emphasize the importance of conceptualizing and analysing a coupled socialecological system in vulnerability assessment, with case studies in Ummannaq, Greenland and Finnmark, Norway. Their work highlights the importance of feedback and interactions between biophysical change (climate variability and change, and linked ecological changes) and social, economic, technological and institutional and policy changes, noting the importance of this work to the emerging field of sustainability science (Clark \& Dickson 2003). An important component of the Arctic climate impact assessment (McCarthy \& Martello 2005) emphasizes that assessment of human vulnerability to climate change in the Arctic must consider social, insti- tutional, economic and biophysical components, as well as community dynamics and local knowledge and values. Communities face stressors and change in each of these components in addition to the biophysical aspects of climate change. Forbes (2008) underscores the importance of equity considerations in adaptation to climate change in conjunction with significant land-use change in the North (for a discussion of equity issues in adaptation to climate change, see also Thomas \& Twyman 2005). In vulnerability research on the resource harvesting sector of Inuit communities in Nunavut, Ford and co-workers emphasize the significance of continuing intergenerational knowledge transfer in cultural tradition and food harvesting skills, enhancement of social networks, flexibility and institutional support (Ford, MacDonald et al. 2006; Ford, Smit et al. 2006; Ford et al. 2007; Ford et al. 2008).

This paper compares the biophysical exposure, the social, cultural and economic sensitivity, and the adaptive capacity of the dominant urban population centre in interior Alaska, with that of rural, predominantly Alaska Native, communities.

\section{Methods and approach}

This paper synthesizes results from an interdisciplinary project that took a systems perspective in analysing the coupled human-fire social-ecological system of the Boreal forest of Alaska (Chapin et al. 2000; Chapin et al. 2003; Calef et al. 2008). We take a general case study approach (Yin 2003), which allows for comparative analysis of quantitative and qualitative data over multiple parameters, including demographic, economic, institutional and social conditions in urban and rural communities. A diverse range of social science methods, outlined below, were employed to conduct a comparative assessment of urban and rural vulnerability to the anticipated changes in the fire regime resulting from a warming climate. Methods and results specific to the feedback between climate and wildfire regime are available in previous publications (Rupp et al. 2000; Duffy et al. 2005; Rupp et al. 2006; Rupp et al. 2007).

We focus our inquiry on interior Alaska, because historically most of the fire activity in Alaska has occurred in this region (Fig. 1). However, because of the similarity in demographic features, road access, population growth and fire management institutions, conclusions here for urban areas would also apply in south-central Alaska, including Anchorage, the Matanuska-Susitna Valley and the Kenai Peninsula, where the wildland-urban interface is expanding and fire risk has increased as a result of the large-scale, climate-related insect-caused mortality of white spruce forests. 
In order to compare urban and rural demographic features, we report both population and income data collected from the 2000 US census. Straightforward comparisons are made between Fairbanks and the Fairbanks North Star Borough (urban), and the Koyukon Athabascan community of Huslia and the Yukon-Koyukuk Census District (rural) that covers the bulk of rural interior Alaska (Fig. 1) (US Census Bureau 2000). These regions and communities were selected to provide urban and rural examples based, in part, on access and the experience of the research team. Fairbanks was selected because it is the largest population centre in interior Alaska. With projected continued population growth, it has high potential exposure to environmental change. Although the majority of rural, native communities in interior Alaska are Athabascan, each community has a unique constellation of subcultural heritage (Koyukon, Gwit'chin, Ahtna and Tanana, etc.), local ecosystem features (upland, lowland, forest, bog and tundra), reliance on subsistence foods (various fish species, moose, caribou, small mammals and birds), political and social strengths and challenges, and leadership for fire and hazardous-fuel related projects (Scott et al. 2001). Huslia was selected as an example of a rural community because several members of the research team are current or former residents, and therefore have relationships with community members that helped to facilitate the completion of the research in accordance with the accepted practice of ethical research in Northern communities (National Science Foundation 2008).

Data on federal-, state- and regional-scale institutional parameters, including communication and collaboration between state and federal agencies, the history and structure of Alaskan fire policy and fire suppression activities in a national context, economic and fiscal constraints in fire suppression, and procedural aspects of urban hazard fuel reduction were collected via semi-structured interview, focus group, observation, survey and workshop. Twenty-six semi-structured, in-person, key-informant interviews, and one focus group with 12 participants, were conducted with leaders and professionals in state and local fire management and suppression, including: the regional director of the state Division of Forestry; the director of the Bureau of Land Management (BLM) Alaska Fire Service; fire management officers and fire ecologists for the BLM, the state Division of Forestry and the US Fish and Wildlife Service; and managers and key personnel in the Alaska Interagency Coordination Center.

During and after the record-breaking 2004 fire season, we observed incident command operations, public informational briefings, and post-fire public meetings. Field notes of observations were recorded by hand, and electronic summaries were written and reviewed for consistency and content. These observations provided data on local-scale fire impacts, communication between fire managers, fire suppression agencies and the public, and urban social psychology related to fire risk.

Data on local, rural social psychology, and cultural norms related to wildfire and related risk, institutional structures and communication between federal and local-scale fire management, and operational details of implementing rural hazard fuel reduction projects were collected at two workshops held in Huslia, Alaska, a rural, mostly Athabascan, community of about 300 people, on the Koyukuk River. Participants in these workshops included elders and representatives from Huslia and other villages (including Kobuk, Allakaket, Hughes, Galena, Kotzebue, Noatak and Nikoli), teachers and students at the Huslia high school, state and federal fire managers, climatologists and members of the research team. The first workshop included discussion of fire in the larger context of local observations and experience of climate change. The second workshop was devoted to discussion of local knowledge about wildfire and fire management, and to discussion of the advantages and disadvantages of hazard fuel-reduction projects surrounding rural villages. This second workshop included a field trip in which experienced representatives from federal agencies and the regional native non-profit organization, Tanana Chiefs Conference, described fuel-reduction projects in specific locations, such as the cemetery and the fuelstorage tank farm. Workshops were recorded, handwritten notes were taken, and workshop summary reports were written and provided to tribal leaders. Notes and summaries were coded by theme. See Huntington et al. (2006) for a detailed analysis of the workshop content.

In order to evaluate economic stressors on rural communities, and the economic and social component of fire-fighting employment in both rural and urban communities, we administered in-person written surveys $(n=35)$, and conducted semi-structured interviews $(n=9)$ with emergency fire-fighting (EFF) crew members, crew bosses and crew boss trainees. Survey questions covered EFF employment history, the role of EFF employment in household and community economy, and demographic information. Surveys were analysed using descriptive statistics (Fink \& Kosecoff 1998). Informants were selected via snowball sampling (Bernard 1995; Holstein \& Gubrium 1995). All interviews were recorded, summarized in electronic form and coded by theme. See Trainor (2006) for a report of survey results.

Our research design and approach thus satisfies key criteria for vulnerability assessment (Turner, Kasperson et al. 2003; Schroter et al. 2005). We draw from a diverse, flexible, interdisciplinary team with a strong local knowl- 
edge base. We conducted a place-based analysis with explicit attention to nested scales, cross-scale interactions and differential variability. We explicitly include multiple, interacting social and biophysical stressors and drivers of change, as well as institutional analysis in both vulnerability adaptive capacity assessments. We consider the exposure and sensitivity of the coupled social-ecological system in the context of directional climate, social and economic changes, and link prospective models of the human-climate-fire system with historical and archival analysis of indigenous use of fire on the landscape.

\section{Results}

\section{Biophysical change}

Climate-related changes in the fire regime can be expected to similarly impact urban and rural communities. Model projections show an increased frequency of extreme fire seasons with climate change (Flannigan et al. 2005; Symon et al. 2005). Duffy et al. (2005) have demonstrated a strong link between summer temperatures, monthly weather and atmospheric teleconnection indices, and the area burned. Specifically, the June temperature alone explains about one-third of the interannual variability in the area burned in Alaska.

Fire is a significant ecological disturbance in the Boreal forest of Alaska. By altering stand composition from dark, heat-absorbing black spruce to light, reflective birch and aspen, wildfire alters surface reflectivity, or albedo. In this way, fire-induced vegetation changes are one of the few regional-scale negative feedback mechanisms countering climate warming at high latitudes (Chapin et al. 2000; Chapin et al. 2005; McGuire et al. 2006). However, this regional cooling effect is not strong enough to counteract the overall warming and drying trends.

Thus, we expect to see an overall increase in annual area burned in interior Alaska as a result of climate warming (Balshi et al. 2008). This will increase the probability of multiple fires occurring simultaneously, creating competing demand for fire suppression resources (equipment, personnel, etc.).

\section{Demographics and economic conditions}

We focus our analysis on two locations in interior Alaska, one urban and one rural, analysing demographic features on both community and borough (county equivalent) scales. Fairbanks is the urban hub of interior Alaska, located in the central Tanana Valley within the Fairbanks North Star Borough, and is situated at the nexus of four paved roads on Alaska's limited road network (Fig. 1). As of the 2000 US census, the municipality of Fairbanks had a population of 30 200, with 10\% Alaska Native, 67\% white and $11 \%$ African heritage. The municipal footprint is $83 \mathrm{~km}^{2}$, with a population density of 370 persons per $\mathrm{km}^{2}$. The 11000 households in the municipality have a median household income of 40600 USD, and a per capita money income of 19800 USD; $10.5 \%$ of the population is below the poverty line. The Fairbanks North Star Borough (FNSB) has a population of 84800 , which increased from April 2000 to July 2006 by 14\%. Whites comprise $79 \%$ of the population, people of African heritage comprise $5.3 \%$ and Alaska Natives comprise $7.8 \%$. The 30000 households in the FNSB have a mean household income of 53000 USD, and a per capita money income of 21500 USD; $8 \%$ of the population live below the poverty line (Table 1). The borough is $19100 \mathrm{~km}^{2}$, with a population density of 4 people per $\mathrm{km}^{2}$. The BLM's Alaska Fire Service Interagency Coordination Center is located in the FNSB, and the Division of Forestry, Alaska Department of Natural Resources, also manages a central dispatch office in Fairbanks. According to the Alaska Department of Fish and Game, $7 \mathrm{~kg}$ of wild foods were harvested per person per year in the larger Fairbanks region (roughly equivalent to the FNSB region) for the

Table 1 Demographic features for Fairbanks, the Fairbanks North Star Borough (FNSB), Huslia and the Yukon-Koyukuk Census District (YKCD). Data are from the 2000 census (US Census Bureau 2000). The USD values are 1999 values, and have not been adjusted.

\begin{tabular}{|c|c|c|c|c|}
\hline & Fairbanks & FNSB & Huslia & YKCD \\
\hline Total population & 30224 & 82840 & 239 & 6551 \\
\hline Population change (1 April 2000-1 July 2006ª) & & $+14.4 \%$ & & $-10.9 \%$ \\
\hline Alaska Native population & $9.9 \%$ & $7.8 \%$ & $93.5 \%$ & $69.9 \%$ \\
\hline White population & $66.7 \%$ & $79.1 \%$ & $4.4 \%$ & $26.9 \%$ \\
\hline Land area $\left(\mathrm{km}^{2}\right)$ & 83 & 19079 & 42 & 377855 \\
\hline Population density (persons per $\mathrm{km}^{2}$ ) & 366 & 4 & 7 & $<1$ \\
\hline Household density (households per km²) & 134 & 2 & 2 & $<1$ \\
\hline Median household income & 40580 USD & 53090 USD & 27000 USD & 30930 USD \\
\hline Per capita money income & 19814 USD & 21553 USD & 10983 USD & 13720 USD \\
\hline Persons below poverty line & $10.5 \%$ & $8 \%$ & $28.1 \%$ & $18.4 \%$ \\
\hline
\end{tabular}

aUS Census Bureau estimate, based on 2000 census. 
Table 2 Annual wild food harvest for the Fairbanks-Delta region and rural interior region. Data are from Wolfe (2000).

\begin{tabular}{lcl}
\hline & $\begin{array}{l}\text { Fairbanks-Delta } \\
\text { region }\end{array}$ & $\begin{array}{l}\text { Rural interior } \\
\text { region }\end{array}$ \\
\hline Annual wild food harvest & 7 & 276 \\
(1990s) (kg per person) & $10 \%$ & $396 \%$ \\
Percentage required protein & $1 \%$ & $57 \%$ \\
Percentage required calories & & \\
\hline
\end{tabular}

decade of the 1990s, supplying $10 \%$ of the required protein and $1 \%$ of the required calories for the regional population (Table 2).

In contrast, the rural Koyukon Athabascan community of Huslia is located in the north-west interior, on the Koyukuk River. It has a population of 293, of which $94 \%$ are Alaska Native and $4 \%$ are white. The land area is $42 \mathrm{~km}^{2}$, with a population density of 7 persons per $\mathrm{km}^{2}$. Like many rural villages in Alaska, Huslia is accessible only by river (barge or boat in the summer, snowmobile in the winter) or air. The 88 households in Huslia have a median household income of 27000 USD, and a per capita money income of 10980 USD; $28.1 \%$ of the population below federal poverty standards. As is most of rural interior Alaska, Huslia is located in the Yukon-Koyukuk Census District (YKCD), which has a total population of 6550 , with $70 \%$ being Alaska Native and $27 \%$ white. In the period from April 2000 to July 2006, the YKCD had a negative population change of nearly $11 \%$. The land area is $377900 \mathrm{~km}^{2}$, with a population density of $<1$ person per $\mathrm{km}^{2}$. The 2300 households in the YKCD have a median household income of 30900 USD, and a per capita money income of 13700 USD; $18.4 \%$ of the population live below the poverty line (Table 1). In the 1990s, wild food harvest in the Alaska Department of Fish and Game rural interior region, which includes Huslia, and most of the rural interior Alaska, was $276 \mathrm{~kg}$ per person per year, providing $396 \%$ of the US recommended daily allowance (USRDA) of protein, and $57 \%$ of the USRDA of calories, an order of magnitude larger than in the Fairbanks region (Table 2).

In summary, the urban area of Fairbanks and vicinity has an order of magnitude greater population and household densities, one and a half times the median household income, and nearly twice the per capita money income than Huslia, and the rural interior. The rural interior has an order of magnitude greater percentage of Alaska Native population, an order of magnitude greater land area and more than double the percentage of persons below the poverty line than in urban Fairbanks and vicinity. In contrast to a $14 \%$ population increase in the urban interior, the rural interior of Alaska lost over $10 \%$ of its population from 2000 to 2006 (based on US census estimates). Additionally, the wild food harvest in the rural interior is an order of magnitude greater per capita, and meets an order of magnitude greater percentage of protein and calorie requirements than in the urban interior.

\section{Organizational structure and institutional relationships}

Table 3 outlines the institutional relationships and lines of communication in wildfire management. Locally, the Fairbanks City government is a single point of contact, whereas rural native villages typically have both city and tribal governing bodies. Similarly, whereas the FNSB is a single point of contact on a regional scale, the rural interior has no centralized regional governmental entity. Unlike the predominantly non-native urban area, rural native villages in interior Alaska are served by a regional native non-profit organization, known as the Tanana Chiefs Conference, and the Bureau of Indian Affairs. In addition to serving health, employment, family services and other community needs, the Tanana Chiefs Conference has a forestry division, and a dedicated community forestry liaison who works with communities to implement hazard fuel reduction projects. There is also a dedicated Bureau of Indian Affairs representative for fire management and employment-related issues.

As there are large areas of fire-prone Boreal forest, and limited financial and personnel resources, fire suppression actions in Alaska, unlike other states in the US, occur according to pre-determined management options on a continuum from full to limited suppression (see Calef et al. 2008). Management options, and therefore the level of fire suppression action, are determined by the landowner, with the state Division of Forestry assigning management options for privately owned lands (Division of Forestry 1998).

People living in rural villages rely on land areas that extend well beyond the village site limits for hunting, fishing and gathering wild foods such as moose, caribou and various fish species. In Huslia, and throughout the majority of the YKCD, this land is managed by the US Fish and Wildlife Service, the BLM or the state of Alaska (Table 4). Thus, although the nutritional needs of local people are closely linked to ecosystem characteristics that are impacted by wildfire (i.e., habitat for wild foods), the decisions about fire suppression and management are made by federal and state agency personnel, according to their agency's priorities and mission, which may or may not align with local knowledge and preferences (interview with D. Hansen, 19 November 2003). As Orville Huntington of Huslia explained, "the people on the ground feel that they're regulated by a higher power", 
Table 3 Institutional relationships and communication in wildfire management in Fairbanks/Fairbanks North Star Borough (FNSB) and Huslia/YukonKoyukuk Census District (YKCD).

\begin{tabular}{|c|c|c|}
\hline & Fairbanks/FNSB (urban) & Huslia/YKCD (rural) \\
\hline Local governing body & City of Fairbanks & Tribal government; City government \\
\hline Regional governing body & Fairbanks North Star Borough & None \\
\hline $\begin{array}{l}\text { Primary land managers/fire } \\
\text { decision makers }\end{array}$ & $\begin{array}{l}\text { Division of Forestry, Alaska Department } \\
\text { of Natural Resources; US military }\end{array}$ & $\begin{array}{l}\text { US Fish and Wildlife Service; Bureau of Land } \\
\text { Management; Division of Forestry, Alaska Department } \\
\text { of Natural Resources }\end{array}$ \\
\hline Intermediary organizations & None & $\begin{array}{l}\text { Tanana Chiefs Conference (pre-suppression, regional) } \\
\text { Bureau of Indian Affairs (federal) }\end{array}$ \\
\hline $\begin{array}{l}\text { Lines of communication between } \\
\text { local governing body } \\
\text { and fire management }\end{array}$ & $\begin{array}{l}\text { Centralized points of contact. However, } \\
2004 \text { fire season illustrated faulty lines } \\
\text { of communication. }\end{array}$ & $\begin{array}{l}39 \text { dispersed communities, each with independent } \\
\text { relationships with federal and state land and fire } \\
\text { managers. Communities work through the Tanana } \\
\text { Chiefs Conference and Bureau of Indian Affairs for } \\
\text { pre-suppression, and directly with Alaska Fire Service } \\
\text { and the state Division of Forestry, for suppression }\end{array}$ \\
\hline
\end{tabular}

Table 4 Land ownership in the Fairbanks North Star Borough (FNSB) and Yukon-Koyukuk Census District (YKCD) as a percentage of the total area (aggregated).

\begin{tabular}{lrr}
\hline & FNSB & YKCD \\
\hline National parks and preserves & 0.21 & 9.48 \\
National wildlife refuges (US Fish and Wildlife & \multicolumn{1}{c}{} & 27.84 \\
$\quad$ Service) & & \\
Bureau of Land Management & 6.28 & 26.63 \\
Military & 18.04 & 0.03 \\
Native & 0.56 & 10.88 \\
State & 67.38 & 24.74 \\
State and Native & 0.09 & 0.09 \\
Private & 7.43 & 0.32 \\
\hline
\end{tabular}

they feel powerless to make decisions that will improve their situation (Huslia workshop, October 2004). The extent to which local concerns about fire and its impact on wild-food habitat are included in federal decision making depends largely upon the interpersonal relationships between federal fire managers and local village leaders (interviews with Bob Lambrecht, 17 February 2004 and 5 March 2004).

Between the years 1998 and 2001, the Tanana Chiefs Conference had three separate resolutions (from Hughes, Yukon Flats Subregion and Allakaket), excerpted below, calling on the Tanana Chiefs Conference to work directly with federal land managers to change fire policy to protect salmon spawning grounds, wildlife habitat and employment.

Now therefore be it resolved that the Tanana Chiefs Board of Directors directs Tanana Chiefs Conference (TCC) Inc. to oppose the "Let burn" [sic] policy (Proposed Resolution No. 98-30, “Let it burn" policy opposition).

Now therefore be it resolved that the Tanana Chiefs Board of Directors direct that TCC staff develop a management program for burning polices within federal refuges in the Region, and that it is done through cooperative efforts from all affected groups (Resolution No. 200-31, Better managed burning polices within the Tanana Chiefs Region).

Now therefore be it resolved that the Tanana Chiefs Board of Directors directs the appropriate department to begin the process of working with BLM to change the let burn [sic] policy by immediately extinguishing wild fires near streams $\&$ rivers (Resolution No. 2001-24, BLM Let burn [sic] policy that adversely affects salmon spawning grounds).

These resolutions illustrate local efforts at increasing their input in fire management (interview with D. Hansen, 19 November 2003). They express disapproval of existing fire management policy, and demonstrate that individual communities have little direct influence on wildfire management in their surrounding area, but use the intermediary organization of the Tanana Chiefs Conference to communicate with federal land and fire managers. However, although the Tanana Chiefs Conference, the Bureau of Indian Affairs and Chugachmiut (the native non-profit organization for south-central Alaska) hold three of the 13 seats on the Alaska Wildland Fire Coordinating Group, the Tanana Chiefs Conference has no direct fire management or fire suppression authority.

With its centralized local and regional governing bodies, and organizational structure, the FNSB has a more direct relationship between local and regional governance and fire management. However, a significant issue during the extreme fire season of 2004 was the lack of communication between fire managers, the public, local relief organizations and local government (Public Meeting, November 2004; Alaska Wildland Fire Coordinating Group 2006). 


\section{Public attitudes and perceptions of fire}

Public attitudes, perceptions and expectations of wildfire, and local, state and federal fire suppression agencies, affect the sensitivity to wildfire (Grothmann \& Patt 2005). In Alaska, populated areas with high potential for loss of life and property (such as cities, suburbia, exurbia and rural villages) receive full suppression. However, in FNSB there are private cabins and secondary residences that are located in areas that receive less than full suppression. Although landowners are notified of this reduced suppression status upon purchase of the land, expressions of frustration and anger were common during the 2004 fire season.

The public sentiment expressed at a public meeting in Fairbanks following the record-breaking 2004 fire season (November 2004) balanced outrage that state and federal fire managers did not control the fire, with frustration that private landowners needed to take more personal responsibility for fire-risk reduction on their property. Although fire managers explained that decisions were made at the time with the best available information, and that fire suppression sustained over decades will eventually create greater risk, community members who had lost property in the fire were hostile and critical of fire management decisions, voicing the assumption that state and federal fire managers can and should control all fire, and protect all property, for example:

Not in my lifetime will I see any benefits from fire on the back of Haystack Mountain. When families and

homes are threatened, I don't buy that the ecosystem

is more important.

It seems that the state has been asleep at the

wheel. (Fairbanks public meeting participant)

Yet other members of the public rebutted this view, expressing the need for people to take personal responsibility for their property:

People who decide to build in a no-protection area

need to take responsibility.

We need to take personal responsibility . . .

Alaskans are famous for not being willing to pay

taxes for resources we need.

(Fairbanks public meeting participant)

These sentiments are congruent with research results elsewhere in the US, which show that people who experience wildfire tend to place causal responsibility for the damage on fire management agencies or on nature (Kumagai 2004), and that public response to wildfire is strongly mediated by emotional response and problem framing (Arvi et al. 2006).

In the rural interior, attitudes and perceptions of fire vary with the geographic distribution and proximity of past fires, and with the local history of fire use to manipulate landscape features (Natcher, Calef et al. 2007). In Huslia, we observed ambiguous attitudes towards fire. The smoke carries health hazards, and fires create hazardous winter travel conditions because of blowdowns in burned areas; wildfire is destructive of property, birds and other animals. Yet, fire generates important household income through EFF (Huntington et al. 2006; Trainor 2006; interview with B. Lambrecht, 5 March 2004). Whereas the federal and state wildlife management agencies often consider fire as beneficial for moose habitat, Huslia elder Catherine Attla explained that, "fire is not good for Native people". Promoting fire as being good for the ecosystem "is the wrong thing to say to the land" (C. Attla, Huslia Workshop, January 2004).

For many in rural communities, fire equates to employment on EFF crews. Although EFF income is a relatively small proportion of the overall village-scale income, EFF work is one of the few jobs available to young rural adults, and is very important on an individual and household basis (Trainor 2006). There are also non-monetary benefits to EFF employment. EFF workers cite the benefits of intergenerational mentoring (crews often employ people from multiple generations, typically with elders as crew bosses), the building of team work and the teaching of employment skills, as the following two quotations from Huslia residents illustrate.

When whole crew goes out, 16 checks come in. Everyone walks around with a smile on their face. There is lots of money in town. The cost of living is going up quickly. When there are no jobs, everybody is in a down mood and they are hard to get along with.

[EFF work] boosts the economy. When we go out together, it brings people closer together ... It teaches responsibility to younger guys. It teaches how to have a job, what's expected in a job, for example, arriving on time, completing a task/assignment, and filling out a time card. (Survey respondent)

Conversely, however, the relatively large influx of money from EFF work can be problematic in small rural villages. One participant in the Huslia fire workshop explained:

Fire-fighting provides income, which is good, but that also contributes to alcoholism, drug abuse, child neglect and kids ending up in foster homes. Not every fire fighter uses their wages to pay their bills or pay for gas. This is a catch-22 because food is scarce so people have to go farther and farther and its getting harder and harder to feed families.

(Huslia workshop participant) 
These sentiments illustrate ambiguity in rural public attitudes and perception regarding fire and fire management.

Further ambiguity in rural attitudes towards fire relates to the inherent threat to life and property, and the ecological consequences. Although fire fighting provides important employment and income, Huslia residents are concerned about their losses to fire, and the impacts on birds, small game, fish, muskrat, beaver, mink, marten and other animals.

One year they let fires burn for moose [habitat] and [some people] lost two trapping cabins ... The BLM gave these people a permit to rebuild the cabin, which they did, but they lost the contents including fish traps, snowshoes and a heater stove ... When they burn for moose [habitat enhancement], they don't think about the small animals like beaver. [I am concerned about] ashes from fires getting into the lakes and sloughs and the affect on fish and water games like muskrat, beaver and mink.

(Summary of interview with C. Attla, 9 March 2004)

Rose explained that "fire burned here naturally". Yet, she was concerned that "all the little games burned up" in fires: the ducks, muskrats and geese. She worried that the eggs of waterfowl also burn up in fires. She explained that fire fighters have come back from fires and told her that they have seen burnt eggs. She continued that rabbits, spruce hens and other fur-bearers used to be around, but that "fires being allowed to burn has destroyed the games" (summary of interview with R. Ambrose, 8 March 2004).

Research on perspectives and attitudes towards fire in rural Alaska Native villages must pay careful attention to cultural and historical context and epistemology. As
Huntington et al. (2006) explain, comments such as "we hate fire" can have multiple meanings. Fire is a powerful force of nature. More than once in our discussions with Huslia residents about fire, our inquiries about fire were rebutted with phrases like, "there are some things you just don't talk about" (anonymous). As Natcher, Huntington et al. (2007) further argue, research inquiry to assess attitudes and perception in "what if" scenarios should be very carefully employed and interpreted in rural Alaska Native villages.

\section{Existing response and adaptation to a changing fire regime}

Table 5 summarizes the actions that state and federal fire mangers have taken, in some cases in close collaboration with communities, to reduce fire exposure and sensitivity in interior Alaska. These changes have occurred in response to policy, management, financial and resource pressures, and not necessarily as a conscious or deliberate adaptation to climate-induced changes in the fire regime. They demonstrate flexibility and adaptive learning by fire managers.

Landscape-scale risk assessments and community-scale fuel management programmes are important adaptive measures that have been implemented to assess fire impacts on wild food subsistence resources, and reduce community fire risk. These programmes have occurred in both urban and rural areas, and include a geographic information system (GIS) catalogue of resources at risk, tree thinning, the removal of trees and other vegetative fuels in the form of fire breaks on a community perimeter, and in some cases prescribed burns. Throughout the state, projects have been managed and sponsored by

Table 5 Existing response and adaptation to a changing fire regime.

\begin{tabular}{|c|c|c|c|}
\hline Action & Entities involved & Purpose & Adaptive outcome \\
\hline $\begin{array}{l}\text { Landscape risk assessment } \\
\text { and community fuel } \\
\text { management programmes }\end{array}$ & $\begin{array}{l}\text { Alaska Fire Service; Tanana Chiefs Conference; } \\
\text { National Park Service; US Fish and Wildlife } \\
\text { Service; Division of Forestry, Alaska Department } \\
\text { of Natural Resources; individual communities }\end{array}$ & Reduce fire risk & $\begin{array}{l}\text { Decrease exposure; increase } \\
\text { communication and collaboration; } \\
\text { both rural and urban }\end{array}$ \\
\hline $\begin{array}{l}\text { Directing suppression } \\
\text { resources towards structure } \\
\text { protection rather than fire } \\
\text { suppression }\end{array}$ & $\begin{array}{l}\text { Alaska Fire Service; Division of Forestry, Alaska } \\
\text { Department of Natural Resources }\end{array}$ & $\begin{array}{l}\text { Protect life and property } \\
\text { with efficient utilization of } \\
\text { resources }\end{array}$ & $\begin{array}{l}\text { Prevent increasing sensitivity in the } \\
\text { face of resource limitations; both } \\
\text { urban and rural }\end{array}$ \\
\hline $\begin{array}{l}\text { Annual revision of fire } \\
\text { management options }\end{array}$ & Landowners/managers & Re-assess values at risk & $\begin{array}{l}\text { Adapt to new development and } \\
\text { changing values }\end{array}$ \\
\hline $\begin{array}{l}\text { Development of community } \\
\text { wildfire protection plans }\end{array}$ & $\begin{array}{l}\text { Fairbanks North Star Borough; Division of } \\
\text { Forestry, Alaska Department of Natural } \\
\text { Resources }\end{array}$ & $\begin{array}{l}\text { Develop wildfire risk } \\
\text { assessment and mitigation } \\
\text { plan }\end{array}$ & $\begin{array}{l}\text { Reduce exposure and sensitivity to } \\
\text { wildfire in urban area }\end{array}$ \\
\hline $\begin{array}{l}\text { Community involvement in } \\
\text { Firewise programme }\end{array}$ & Individual communities; federal fire managers & Reduce fire risk & $\begin{array}{l}\text { Public education, learning, } \\
\text { engagement; both urban and rural }\end{array}$ \\
\hline
\end{tabular}


local, state, federal and non-profit institutions, and land management agencies, including the BLM's Alaska Fire Service, the Tanana Chiefs Conference, the US Fish and Wildlife Service and the Alaska Department of Natural Resources. Especially in rural areas, these projects provide important employment opportunities, and represent cooperation between state/federal agencies and communities. These programmes take advantage of available federal funding to reduce wildfire risk, and have not necessarily been implemented in direct or deliberate response to knowledge of climate-related changes in the fire regime. However, the protection they provide will help reduce sensitivity to these changes.

Strategically directing suppression resources towards structure protection, rather than attempting to control fire movement, is another fire management action that demonstrates flexibility and the capacity to adapt to environmental, economic and policy constraints. Wildfire is more easily extinguished or controlled early, when it covers a relatively small area (DeWilde 2003). Once a wildfire has reached a critical size it is much more effective, and resource-efficient, to focus water pumps and suppression labour resources directly on protecting specific structures or values at risk, than to attempt to control the fire per se. This fire suppression strategy, which illustrates the capacity for learning and innovation, has evolved in Alaska in response to large land areas and limited suppression resources, yet it is also an effective way to protect life and property with the increasing exposure to fire resulting from climate change (interview with C. Maisch, 30 April 2004).

The Alaska Interagency Wildland Fire Management Plan sets out a continuum of fire management strategies from full suppression to limited suppression (Division of Forestry 1998; Calef et al. 2008). This innovative policy was established in order to protect life and property over a vast geographic area, while taking best advantage of limited fire suppression resources. The fire management option for any parcel of land is determined by the landowner (e.g., the BLM, National Park Service, US Fish and Wildlife Service, Native Corporation or the state Division of Forestry, for private property). Fire management classifications are revised annually to update values at risk and the habitat enhancement values of fire (e.g., new development/structures, long-term benefits for moose browse). This annual re-evaluation of fire suppression management options demonstrates how fire policy and management in Alaska has a built-in adaptive feature to re-assess the degree of fire suppression on any give parcel of land, based on new development and/or evolving land management values and strategies (interview with Chris Maisch and Tom Kurth, 30 April 2004; interview with Dale Haggstrom, 27 October 2003).
The 2006 Community Wildfire Protection Plan for At-Risk Communities in the FNSB, Alaska is another example of adaptation to fire risk involving enhanced communication and direct collaboration between FNSB and the state Division of Forestry (Division of Forestry 2006). Taking advantage of available federal funding, this plan illustrates adaptive learning to the constellation of conditions and events that led to the record-breaking 2004 fire season. It puts forward objectives to: (1) "[e]stablish an exposure model for the borough that rates risk and complete a wildfire protection plan", (2) "[r]educe risk of hazardous fuels through fuels reduction silvicultural treatments", (3) "[r]educe the risk from wildfire to life and property by education and community outreach", (4) "[r]educe risk of escaped fire by improving the effectiveness of fire suppression resources", and (5) establish "[c]ommunity planning". A similar plan has been completed for the municipality of Anchorage, and others are planned for additional urban areas in the state.

Another adaptive response to an increasingly active fire regime has been community involvement in a federal Firewise programme. This is an established, nation-wide, multi-agency programme for homeowner and community action to reduce fire risk on private property (National Fire Protection Association 2008). Implementing Firewise programmes and initiating similar community-scale fuel reduction projects can decrease exposure to climate-induced changes in the fire regime. The community of Cohoe responded to an extensive 2007 fire season by becoming the second town in Alaska to be officially designated a Firewise community (Cejnar 2007). During and after the record-breaking 2004 fire season, Firewise workshops and fuel reduction projects were conducted in over 15 rural and urban communities (Alaska Wildland Fire Coordinating Group 2006).

\section{Discussion}

How does vulnerability to a changing fire regime compare between urban and rural communities in interior Alaska? In what ways do exposure, sensitivity and adaptive capacity differ between these types of communities? Table 6 summarizes this comparison.

\section{Exposure}

Exposure to fire risk in the human-climate-fire system of interior Alaska is largely governed by the biophysical impacts of climate change, coupled with demographic and economic features. Overall, we can expect the biophysical impacts of climate change to increase exposure comparably in both urban and rural communities. 
Table 6 Summary of exposure, sensitivity and adaptive capacity to increased fire occurrence for urban (Fairbanks) and rural (Huslia) communities.

\begin{tabular}{|c|c|c|}
\hline & Urban/Fairbanks & Rural/Huslia \\
\hline \multicolumn{3}{|c|}{ Biophysical: climate change $\rightarrow \uparrow$ fire frequency, vegetation drying } \\
\hline \multirow[t]{4}{*}{ Exposure } & $+\uparrow$ population & $-\downarrow$ population \\
\hline & $\uparrow$ wildland-urban interface & low population density \\
\hline & high population density & \\
\hline & & + Greater reliance on wildfoods and subsistence species \\
\hline \multirow[t]{2}{*}{ Sensitivity } & $\begin{array}{l}\text { + Attitudes and perceptions: inaction for fire preparedness, view } \\
\text { that fire suppression is the responsibility of the government }\end{array}$ & $\begin{array}{l}\text { + Attitudes and perceptions: income from fire-fighting jobs, } \\
\text { risk of property loss }\end{array}$ \\
\hline & & $\begin{array}{l}\text { + Delayed suppression response due to necessary transport of } \\
\text { crews and equipment to remote, off-road sites }\end{array}$ \\
\hline \multirow[t]{3}{*}{ Adaptive capacity } & + More financial resources & + Fewer financial resources \\
\hline & $\begin{array}{l}\text { + Centralized points of contact between local government and } \\
\text { fire managers/decision makers (evidenced by Fairbanks North } \\
\text { Star Borough's community wildfire plan) }\end{array}$ & $\begin{array}{l}\text { - Decentralized points of contact between local government } \\
\text { and fire managers/decision makers }\end{array}$ \\
\hline & $\begin{array}{l}\text {-l+ Faulty communication during } 2004 \text { fire season, yet relatively } \\
\text { greater potential for improvement. }\end{array}$ & $\begin{array}{l}\text { - Cultural barriers. Weak communication, yet recognition that } \\
\text { improvement is necessary. }\end{array}$ \\
\hline
\end{tabular}

Vertical arrows $(\uparrow / \downarrow)$ denote increasing or decreasing trends, horizontal arrows $(\rightarrow)$ denote "results in", + denotes positive and - denotes negative exposure and sensitivity. The biophysical impacts of climate change are common to both urban and rural communities (centred in the row). Other features, such as reliance on wild foods, delayed suppression response, financial resources and institutional connections, vary between urban and rural communities.

However, demographic and economic dynamics differ between the two types of communities. As noted above, from April 2000 to July 2006, the population in FNSB increased by $14.4 \%$, and the population in YKCD decreased by $10.9 \%$ (Table 1 ). In addition, state land disposal policies and a current lack of zoning restrictions have increased the number of remote cabins in inaccessible, fire-prone areas (Juneau Bureau 2004). If population growth and exurban sprawl continues on its current trajectory, then the wildland-urban interface will expand considerably, increasing the overall exposure to and initiation of fire, in both urban and suburban areas (Calef et al. 2008). With fewer people affected, population decrease in rural areas diminishes exposure (Table 6).

The reliance on wild foods in rural communities is another element of exposure. Rural communities harvest two orders of magnitude more wild foods per capita, and derive an order-of-magnitude greater proportion of protein and caloric intake from these foods than do interior urban dwellers. Rural residents of interior communities rely on wild game to feed their families and to maintain cultural traditions. These people now live in fixed communities and no longer move across the landscape following game (Natcher, Calef et al. 2007). Compared with analogous impacts on urban-based recreational hunters, rural communities are thus more sensitive to wildfire, as it affects both land and animals.

In addition, largely because of game availability, which is influenced by topography, vegetation and disturbance history, some communities are more reliant on moose to fulfil protein requirements, whereas others rely more heavily on caribou (Nelson et al. 2008). This results in disparate vulnerability to fire risk among rural communities, because habitat for moose and caribou are differentially impacted by wildfire. Whereas prime moose forage (willow [Salix spp.]) can be expected to regenerate approximately 10-15 years post-fire, caribou forage (caribou lichen [Cladonia spp.]) will not regenerate until nearly a century post-fire (Huntington et al. 2006; Rupp et al. 2006; Natcher, Calef et al. 2007; Calef et al. 2008; Nelson et al. 2008).

\section{Sensitivity}

The biological and social factors that contribute to the sensitivity of the climate-fire-human system in interior Alaska include geographic isolation, local attitudes, perceptions of fire and fire risk, and local economic conditions. A history of fire suppression in the immediate vicinity of both urban and rural communities increases vegetation flammability, and thus fire risk, in the near future. However, urban and rural communities (especially those not on the road system) are affected differently by distance and time for the arrival of suppression resources, and attitudes and perceptions about fire. Yet, sensitivities to wildfire are strong in both urban and rural communities.

Rural communities face added sensitivity to increased fire activity because of their remote location. Most rural communities in interior Alaska are situated along rivers, and have air access, but are not located on the road system. Summer fish camps and remote trapping cabins located $30-50 \mathrm{~km}$ from the village are especially sensitive 
to wildfire. Although professional and organized state and federal fire suppression forces do their best to dispatch resources to remote locations when fire threatens life and property, the off-road villages are more sensitive to the immediate effects of wildfire close to the village, simply because of the necessarily extended time in transporting fire crews to the scene. Consequently, they must rely on people in the village or camp for immediate fire suppression resources until professional crews arrive. Whereas some villages have heavy equipment available for use in fire suppression, residents may or may not have fire training, do not have protective clothing and may lack other necessary tools. As such, remote rural villages and summer fish camps have increased sensitivity to wildfire risk exposure because of the extended time required to dispatch formal suppression resources to protect life and property.

Public attitudes and perceptions of fire impact a community's sensitivity by affecting physical and psychological preparedness, and ability to respond. The extent to which the community at large and the fire managers are open to continued communication, including public response to wildfire education programmes and manager response to cross-cultural communication enhancement, will impact a community's adaptive capacity (see below).

The ambiguous attitudes towards fire that we observed in Huslia point to a need for continued and enhanced cross-cultural communication between local residents, and governments and fire managers. Individuals and families in rural communities are highly sensitive to income from EFF employment, as well as to fire impacts on private property, transportation and ecosystems. In Fairbanks, we observed the perception that the state and federal government should carry responsibility for wildfire protection of private homes, as well as the perception that individuals should take more responsibility and be more pro-active for fire safety on their property. Areas in which residents attribute fire safety responsibility to the government will be less prepared for, and thus more sensitive to, changes in fire regime.

\section{Adaptive capacity}

Adaptive capacity is the ability of a system to adjust, to moderate potential damage, to take advantage of opportunities and to cope with the consequences of climatic or other change. It is moderated by social and ecological diversity, response to temporal variability and change, the existence of legacies and proximity to social and ecological thresholds, and capacity for innovation and learning (Chapin et al. 2004). In rural indigenous communities, additional factors such as traditional knowledge, flexibil- ity and diversity in resource use, mobility, and strong social networks are important components of adaptive capacity (Ford, MacDonald et al. 2006). These system features manifest at various scales from the individual, to the community, to the state, federal or international institutions. The ability of a community to adjust to changes in the fire regime will depend on communication with fire managers, access to accurate information, community leadership and available resources.

With the urban per capita money income and median household income being, respectively, twice and a third again that of the rural interior, urban communities have more financial resources overall to buffer the impacts of an intensifying fire regime. For example, in Fairbanks, during the extreme fire season of 2004, publicly available, indoor smoke-free areas were established in public buildings, with sufficient heating, ventilation and airconditioning systems to provide relief from hazardous air conditions caused by wildfire smoke to elderly people and other sensitive populations. People with sufficient financial resources in urban areas on the road system could likewise leave the unhealthy air in Fairbanks, and travel by car to coastal communities for relief and smoke-free air. In contrast, most rural communities have few if any facilities to establish safe zones from unhealthy air caused by wildfire smoke. Expensive air evacuation is a last resort for the elderly, those suffering from asthma and small children. In some cases, when air evacuation is requested, it cannot be accomplished because of the poor visibility from the smoke.

Organizational structure, institutional relationships and communication networks between communities and fire management agencies, all contribute to adaptive capacity. With centralized points of contact in regional government, state and federal fire managers have a more direct line of communication with the FNSB. Rural interior Alaska lacks a regional-scale governmental entity that parallels the FNSB government. Decentralized rural municipal and tribal governments must therefore communicate directly with state and federal agencies regarding fire management and planning, or through intermediary organizations. Although efforts are being made to overcome them, barriers in intercultural communication between fire managers and Alaska Native communities remain, hampering rural adaptive capacity. The 2006 Community Wildfire Protection Plan for the FNSB demonstrates the ability of fire managers and local government to work together and create solutions to respond to urban fire risk.

Communities, both urban and rural, and individuals that are proactive, and take responsibility for preventative measures, such as Firewise and hazard fuel reduction, will be less vulnerable. The factors that contribute to 
taking leadership in this realm are thus part of adaptive capacity. For example, after the record-breaking 2004 fire season, several rural communities requested Firewise presentations and projects (Alaska Wildland Fire Coordinating Group 2006). Adaptive capacity is a dynamic property that is linked to public perception. Strong communication between local government, the public and fire managers will enhance adaptive capacity.

Past public education campaigns have been effective in communicating a need for fire suppression and prevention, and in influencing attitudes and perceptions of fire (Pyne 1982). As one fire manager explained, alluding to the well-known icon of the federal wildfire prevention advertisement campaign since the 1940s, "We've done a good job of 'Smokey Bear-ing' people" (B. Lambrecht, 17 February 2004). However, by de-emphasizing the dangers of fuel build-up that accompany sustained suppression, they have also set a trajectory that may impede adaption to our changing fire regime.

Reducing vulnerability to a changing fire regime could be achieved in several ways. First, more extensive, systematic hazard fuel reduction programmes in select locations immediately surrounding urban and rural villages can decrease sensitivity to an intensifying fire regime. At the same time, wood harvested from these projects can be used as biofuel for renewable electricity and heat generation in rural communities. In rural communities, this reduction in biophysical risk can simultaneously assist in reducing social, cultural and economic vulnerability by increasing energy self-sufficiency, reducing fuel costs and creating local employment. Modelling indicates that for many communities there would be a strongly positive economic payback for installing woodfired systems (Fresco 2006). Employing and training rural native youth for hazard fuel reduction projects may dove-tail with suicide prevention programmes, creating multiple benefits. Because these projects will necessarily engage state and/or federal land and fire managers in their planning and implementation, they will also enhance communication and organizational networks. Projects such as these would need to pay close attention to avoid overharvest, to ensure social equity in harvest practice and to dynamically consider potential shifts from conifer to deciduous forest as a result of climate change. In summary, implementing combined hazard fuel reduction/biofuel projects would increase diversity of heating and employment sources, build institutional networks between local communities and state and federal agencies, and address the multiple stressors of climate change and economic strain.

Second, enhanced communication between fire managers (federal and state) and local and tribal governments will make relevant decision makers at local and regional scales aware of the values, perceptions and constraints on local levels, and vice versa. In rural areas, continued and improving efforts at cross-cultural communication are important elements for improving flexibility and responsiveness to changing environmental conditions. These can be accomplished via in-house cultural sensitivity training, and by enhancing existing avenues for communication and opportunities for collaborative projects.

Third, in urban, suburban and exurban areas, such as the City of Fairbanks and the FNSB, exposure to increasing fire activity can be reduced by explicitly including fire risk and costs of fire suppression in local and regional planning, and encouraging homeowners to take more responsibility for fire safety on their properties. This will involve public education, building institutional capacity within local government, social consciousness about inherent fire risk and neighbourhood social networks. For example, local housing covenants, building requirements or insurance requirements could reduce exposure by requiring homeowners to implement Firewise standards on their properties (Division of Forestry 2008). Public education programmes can help build awareness that fire is an integral part of the Boreal forest ecosystem, an annual phenomenon that should be expected and for which the public should prepare. Furthermore, in addition to gearing up to withstand extreme cold, the building industry can help reduce sensitivity to fire by promoting fire-resistant materials such as cellulose fibre-cement house siding. In rural communities, improving facilities for waste disposal can reduce escaped dump fires and related toxic exposures.

Lessons can be drawn from Australia, where homeowners are encouraged to prepare extensively for wildfire, including collecting rain water, installing external sprinkler systems, assembling protective clothing and fire fighting tools, and removing hazard fuels. In the face of fire danger, homeowners decide for themselves whether to stay to protect their properties or to leave, eliminating mandatory evacuations. Strong nongovernmental support systems, including community communication networks, meetings and the organized collaborative fire guard, facilitate fire preparedness and protection. This Australian paradigm contrasts with the dominant actions and attitudes in America, and may serve as a useful model for learning and innovation in adaptation to an intensifying fire regime in Alaska, and throughout the American West (Druzin 2007; O'Donnell 2007).

Similarly, with the sale of remote state parcels of land and as the Fairbanks region grows via the sale of borough and state land for development, government entities can evaluate how the revenue from land sales and taxes compares with the long-term cost of fire protection. 
Public education on the risks of purchasing in low fire protection areas would also be advised.

An individual's, household's or community's capacity to adapt to climatic stressors, such as increasing wildfire risk, is strongly influenced by economic, political and cultural dynamics on multiple scales (Leichenko $\delta$ O'Brien 2002). Subsets of the population experience varying vulnerability and adaptive capacity to climate and non-climate stressors (Adger \& Kelly 1999; Turner, Kasperson et al. 2003; Schroter et al. 2005). In many cases, vulnerability to climate and other environmental stressors (or hazards) is closely linked to the scale of analysis, and to additional community stresses on economic, health, nutritional, cultural and social conditions (O'Brien, Leichenko et al. 2004; O'Brien, Sygna et al. 2004). For example, in rural Alaska issues of suicide, drug and alcohol addiction, out-migration, lack of education and pressures for assimilation often overshadow community awareness of fire prevention and adaptive capacity (Borowsky et al. 1999).

Climate-induced change in fire regime is just one of many different stressors, both climate and non-climate related, facing urban and rural communities in interior Alaska. Other impacts from climate change, both urban and rural, include: permafrost thaw related to increased drainage and surface drying (this involves a positive feedback to increased fire risk from climate change; Jorgensen et al. 2001); damage to public and private infrastructure (Larsen et al. 2008); changes in seasonality (i.e., earlier spring thaw, later fall freeze), and impact on vegetation, availability of and access to subsistence game (Keyser et al. 2000), and on rural transportation and safety; unpredictable weather patterns; changes in migration patterns of game and water fowl; and changes in tourism and growing seasons (Krupnik \& Jolly 2002; Symon et al. 2005). Especially for Alaska Natives in rural communities, additional, non-climatic stressors including high energy costs, other economic pressures, political change, challenges of cultural revitalization, environmental contamination, and compromised physical and mental health are also important features of this system that effect overall individual, household and community resilience (Huntington et al. 2006). Additional work is needed to understand the complex interactions and feedback between multiple climate and non-climate stressors in these communities.

The overall impact of climate change on Northern communities, indigenous and non-indigenous, is yet to be determined (Duerden 2004). Although there are and will continue to be many adverse impacts, climate change will also bring a range of opportunities. However, the extent to which communities, and the region as a whole, can achieve a net gain as they adapt to both the detrimental and beneficial impacts of climate change will depend on: (1) the dissemination of accurate and usable information related to scenarios of projected climate impacts; (2) the ability of communities and leadership to comprehend and accept the reality of the projected change; (3) the constellation of social, economic and political capacity to take proactive, innovative action, and work against institutional inertia, which maintains the status quo; and (4) the development of social networks and safety nets.

What can this analysis tell us about potential vulnerabilities to wildfire in other circumpolar countries? We can anticipate similar biophysical changes in other Boreal forest areas (in Canada, Russia and Fennoscandia), in terms of increasing temperatures, drying fuels, increasing insect cycles, increasing fuel loads and permafrost thaw, creating general surface drying (Soja et al. 2007). Thus, biophysical exposure to wildfire can be expected to increase similarly throughout the circumpolar sub-Arctic. However, different populations will have varying degrees of sensitivity and adaptive capacity to this changing fire regime, depending on demographic, economic and cultural factors, and the institutional and policy structure of state-sponsored fire suppression (Ford et al. 2008). International communication in the form of formal and informal information sharing and lobbying networks have been effective in organizing Arctic peoples to exert political pressure for the mitigation of climate change (Inuit Circumpolar Conference 2005; Watt-Cloutier et al. 2005). People who live in the Boreal forest of the subArctic are also impacted by climate change, including increased vulnerability to wildfire. Similar circumpolar communication and coordination, which builds international networks, including adaptations to a changing fire regime, may increase local and regional adaptive capacity.

\section{Conclusions}

This paper explores the differences that exist in urban and rural vulnerability to climate-induced changes in the fire regime of interior Alaska. We made use of a variety of social science methods, including demographic analysis, semi-structured interviews, surveys, workshops and observations of public meetings. This work was part of an interdisciplinary study of feedback and interactions between climate, vegetation, fire and human components of the Boreal forest social-ecological system of interior Alaska.

Building on the framework of vulnerability and adaptation of the IPCC, this research shows the importance of considering multiple stressors as well as adaptation strategies that can reduce vulnerability on multiple fronts. Although some features are parallel between urban and rural communities, important differences exist in 
vulnerability to climate-induced changes to the fire regime. These differences are linked most closely to economic, social, political and cultural factors, which are not biophysical components of climate change per se.

Of note is that adaptive actions to climate change can occur inadvertently, with the reduction of vulnerability to climate change being an unintended consequence of changes in fire management and suppression strategy. These changes may be motivated by local or regional scale economic, logistical, political or social pressures, or by policy mandates at a national scale. This research highlights the importance of conducting vulnerability assessments with an interdisciplinary view of the coupled social-ecological system, and highlights the role of public perception and institutional connectivity in assessing variable vulnerabilities to climate change.

\section{Acknowledgements}

The work reported here was funded by the National Science Foundation Office of Polar Programs, grant no. 0328282. We thank the community and tribal council of Huslia, Alaska, Chris Maisch and the Alaska Division of Forestry, Scott Billing and the Alaska Fire Service, Bob Lambrecht and the US Fish and Wildlife Service, Doug Hansen, Jim Bell and the Tanana Chiefs Conference, and all of the EFF crew members and crew bosses that participated in this study. The authors are also grateful for very helpful suggestions from two anonymous reviewers.

\section{References}

Adger W.N. \& Kelly P.M. 1999. Social vulnerability to climate change and the architecture of entitlements. Mitigation and Adaptation Strategies for Global Change 4, 253-266.

Alaska Wildland Fire Coordinating Group 2006. Recommendation table update. Ft. Wainwright, AK: Alaska Wildland Fire Coordinating Group, Alaska Fire Service.

AMQA (Air Monitoring and Quality Assurance) 2004. 2004 wildfire season summary. Air Monitoring and Quality Assurance, Division of Air Quality, Alaska Department of Environmental Conservation. Accessed on the internet at www.dec.state.ak.us/air/am/2004_wf_sum.htm on 27 December 2008.

Arvi J., Gregory R., Ohlson D., Blackwell B. \& Gray R. 2006. Letdowns, wake-up calls, and constructed preferences: people's responses to fuel and wildfire risks. Journal of Forestry 104, 173-181.

Balshi M.S., McGuire A.D., Duffy P., Flannigan M., Walsh J. $\&$ Melillo J. 2008. Assessing the response of area burned to changing climate in western Boreal North America using a multivariate adaptive regression splines (MARS) approach. Global Change Biology 15, 578-600.
Bennet J.W. 1996. Human ecology as human behavior: essays in environmental and development anthropology. New Brunswick, NJ: Transaction Publishers.

Berkes F. \& Folke C. 1994. Investing in cultural capital for sustainable use of natural resources. In A.M. Jansson et al. (eds.): Investing in natural capital: the ecological economics approach to sustainability. Pp. 128-149. Washington, D.C.: Island Press.

Berkes F. \& Folke C. 1998. Linking social and ecological systems for resilience and sustainability. In F. Berkes \& C. Folke (eds.): Linking social and ecological systems: management practices and social mechanisms for building resilience. Pp. 1-25. Cambridge: Cambridge University Press.

Bernard H.R. 1995. Research methods in anthropology. Walnut Creek, CA: Alta Mira Press.

Borowsky I.W., Resnick M.D., Ireland M. \& Blum R.W. 1999. Suicide attempts among American Indian and Alaska Native youth: risk and protective factors. Archives of Pediatrics and Adolescent Medicine 153, 573-580.

Brunson M.W. \& Shindler B.A. 2004. Geographic variation in social acceptability of wildland fuels management in the western United States. Society and Natural Resources 17, 661-678.

Calef M.P., McGuire A.D. \& Chapin F.S. III 2008. Human influences on wildfire in Alaska from 1988 through 2005: an analysis of the spatial patterns of human impacts. Earth Interactions 1, article no. 1, doi: 10.1175/2007EI220.1.

Cejnar J. 2007. New station ready for business, open house planned for facility; Cohoe gets Firewise certification. Peninsula Clarion, 12 July. Accessed on the internet at www.peninsulaclarion.com/stories/071207/ news_3077.shtml on 27 December 2008.

Chapin F.S. III, McGuire A.D., Randerson J., Pielke R. Sr., Baldocchi D., Hobbie S.E., Roulet N., Eugster W., Kasischke E., Rastetter E.B., Zimov S.A. \& Running S.W. 2000. Arctic and Boreal ecosystems of western North America as components of the climate system. Global Change Biology 6(S1), 211-223.

Chapin F.S. III, Oswood M.W., Cleve K.V., Viereck L.A. \& Verbyla D.L. (eds.) 2006. Alaska's changing Boreal forest. New York: Oxford University Press.

Chapin F.S. III, Peterson G., Berkes F., Callaghan T.V., Angelstam P., Apps M., Beier C., Bergeron Y., Crein A.-S., Danell K., Elmqvist T., Folke C., Forbes B., Fresco N., Juday G., Niemela J., Shvidenko A. \& Whiteman G. 2004. Resilience and vulnerability of northern regions to social and environmental change. Ambio 6, 344-349.

Chapin F.S. III, Rupp T.S., Starfield A.M., DeWilde L., Zavaleta E., Fresco N., Henkelman J. \& McGuire D.A. 2003. Planning for resilience: modeling change in human-fire interactions in the Alaskan Boreal forest. Frontiers in Ecology and the Environment 1, 255261.

Chapin F.S. III, Sturm M., Serreze M.C., McFadden J.P., Key J.R., Lloyd A.H., McGuire A.D., Rupp T.S., Lynch A.H., Schimel J.P., Berigner J., Chapman W.L., Epstein H.E., Euskirchen E.S., Hinzman L.D., Jia G., Ping C.-L., Tape 
K.D., Thompson C.D.C., Walker D.A. \& Welker J.M. 2005. Role of land-surface changes in Arctic summer warming. Science 310, 657-660.

Chapin F.S. III, Trainor S.F., Huntington O., Lovecraft A.L., Zavaleta E., Natcher D.C., McGuire D., Nelson J., Ray L., Calef M., Fresco N., Huntington H.P., Rupp T.S., DeWilde L. \& Naylor R.A. 2008. Increasing wildfire in Alaska's Boreal forest: pathways to potential solutions of a wicked problem. BioScience 58, 531-540.

Clark W.C. \& Dickson N.M. 2003. Sustainability science: the emerging research program. Proceedings of the National Academy of Sciences 100, 8059-8061.

DeWilde L. 2003. Human impacts on the fire regime of interior Alaska. Master's thesis, University of Alaska.

Dietz T., Ostrom E. \& Stern P.C. 2003. The struggle to govern the commons. Science 302, 1907-1912.

Division of Forestry 1998. Alaska Interagency Wildland Fire Management Plan. Anchorage: Division of Forestry, Alaska Department of Natural Resources.

Division of Forestry 2006. Community wildfire protection plan. Anchorage: Division of Forestry, Alaska Department of Natural Resources.

Division of Forestry 2008. Firewise communities USA. How to become an Alaskan Firewise community. Division of Forestry, Alaska Department of Natural Resources. Accessed on the internet at www.dnr.state.ak.us/forestry/ fire/firewise.htm on 27 December 2008.

Druzin H. 2007. Experts: some wildfire policies put residents at risk. The Idaho Statesman, 4 September. Accessed at www.idahostatesman.com on 27 December 2008.

Duerden F. 2004. Translating climate change impacts at the community level. Arctic 57, 204-212.

Duffy P.A., Walsh J.E., Mann D.H., Graham J.M. \& Rupp T.S. 2005. Impacts of large-scale atmospheric-ocean variability on Alaskan fire season severity. Ecological Applications 15, 1317-1330.

Fastie C.L., Lloyd A.H. \& Doak P. 2002. Fire history and postfire forest development in an upland watershed of interior Alaska. Journal of Geophysical Research-Atmospheres 107, article no. 8150, doi: 10.1029/2001JD000570.

Field D.R. \& Jensen D.A. 2005. Humans, fire, and forests: expanding the domain of wildfire research. Society and Natural Resources 18, 355-362.

Fink A. \& Kosecoff J. 1998. How to conduct surveys. Thousand Oaks, CA: Sage.

Flannigan M.D., Amiro B.D., Logan K.A., Stocks B.J. \& Wotton B.M. 2006. Forest fires and climate change in the 21 st century. Mitigation and Adaptation Strategies for Global Change 11, 847-859.

Flannigan M.D., Logan K.A., Amiro B.D., Skinner W.R. and Stocks B.J. 2005. Future area burned in Canada. Climatic Change 72, 1-16.

Forbes B.C. 2008. Equity, vulnerability and resilience in social-ecological systems: a contemporary example from the Russian Arctic. Equity and the Environment 15, 203-236.

Ford J., Pearce T., Smit B., Wandel J., Allurut M., Shappa K., Ittusujurat H. \& Qrunnut K. 2007. Reducing vulnerability to climate change in the Arctic: the case of Nunavut, Canada. Arctic 60, 150-166.

Ford J.D., MacDonald J., Smit B. \& Wandel J. 2006. Vulnerability to climate change in Igloolik, Nunavut: what we can learn from the past and present. Polar Record 42, 127-138.

Ford J.D. \& Smit B. 2004. Framework for assessing the vulnerability of communities in the Canadian Arctic to risks associated with climate change. Arctic 57, 389400.

Ford J.D., Smit B. \& Wandel J. 2006. Vulnerability to climate change in the Arctic: a case study from Arctic Bay, Canada. Global Environmental Change 16, 145-160.

Ford J.D., Smit B., Wandell J., Allurut M., Shappa K., Ittusarjuat H. \& Qrunnuts K. 2008. Climate change in the Arctic: current and future vulnerability in two Inuit communities in Canada. The Geographic Journal 174, 45-62.

Fresco N. 2006. Carbon sequestration in Alaska's Boreal forest: planning for resilience in a changing landscape. $\mathrm{PhD}$ thesis, University of Alaska.

Fussel H.-M. \& Klein R.J.T. 2006. Climate change vulnerability assessments: an evolution of conceptual thinking. Climatic Change 75, 301-329.

Gardner P.D., Cortner H.J. \& Widaman K. 1987. The risk perceptions and policy response toward wildland fire hazards by urban home-owners. Landscape and Urban Planning 14, 163-172.

Grothmann T. \& Patt A. 2005. Adaptive capacity and human cognition: the process of individual adaptation to climate change. Global Environmental Change 15, 199-213.

Hanna S.S., Folke C. \& Mäler K.-G. (eds.) 1996. Rights to nature: ecological, economic, cultural, and political institutions of the environment. Washington, D.C.: Island Press.

Holling C.S., Berkes F. \& Folke C. 1998. Science, sustainability and resource management. In F. Berkes $\delta$ C. Folke (eds.): Linking social and ecological systems: management practices and social mechanisms for building resilience. Pp. 342-362. Cambridge: Cambridge University Press.

Holstein J.A. \& Gubrium J.F. 1995. The active interview. Thousand Oaks, CA: Sage.

Honigman J.J. 1983. Adaptations in Canadian circumpolar towns. In L. Muller-Wille et al. (eds.): Consequences of economic change in circumpolar regions. Pp. 149-162. Edmonton: Boreal Institute for Northern Studies, University of Alberta.

Huntington H.P., Trainor S.F., Natcher D.C., Huntington O., DeWilde L. \& Chapin F.S. III 2006. The significance of context in community-based research: understanding discussions about wildfire in Huslia, Alaska. Ecology and Society 11(1), article no. 40.

Huntington O. \& Huntington H. 2005. "We hate fire": understanding statements on context. Naalaktuaqtuni Ilitchiruni-Lu, Listening and Learning, Alaska Native Science Commission Newsletter 5(2), 1-2.

Inuit Circumpolar Conference 2005. Petition to the Inter American Commission on Human Rights seeking relief from 
violations resulting from global warming caused by acts and omissions of the United States. Accessed on the internet at http://inuitcircumpolar.com/files/uploads/icc-files/ FINALPetitionSummary.pdf on 10 February 2009.

IPCC (Intergovernmental Panel on Climate Change) 2007. Summary for policymakers. In M.L. Parry et al. (eds.): Climate change 2007: impacts, adaptation and vulnerability. Contribution of Working Group II to the fourth assessment report of the Intergovernmental Panel on Climate Change. Pp. 7-22. Cambridge: Cambridge University Press.

Jorgensen M.T., Racine C.H., Walters J.C. \& Osterkamp T.E. 2001. Permafrost degradation and ecological changes associated with a warming climate in central Alaska. Climatic Change 48, 551-579.

Juneau Bureau 2004. House OKs bill revamping remote cabin program. Daily News Miner. Fairbanks, AK. Accessed on the internet at http://nl.newsbank.com/nl-search/we/ Archives on 9 January 2009.

Kasischke E.S., Rupp T.S. \& Verbyla D.L. 2006. Fire trends in the Alaskan Boreal forest region. In F.S. Chapin III et al. (eds.): Alaska's changing Boreal forest. Pp. 285-301. Oxford: Oxford University Press.

Kelly P.M. \& Adger W.N. 2000. Theory and practice in assessing vulnerability to climate change and facilitating adaptation. Climatic Change 47, 325-352.

Keskitalo E.C. 2004. A framework for multi-level stakeholder studies in response to global change. Local Environment 9, 425-435.

Keyser A.R., Kimball J.S., Nemani R.R. \& Running S.W. 2000. Simulating the effects of climate change on the carbon balance of North America high-latitude forests. Global Change Biology 6(S1), 185-195.

Kneeshaw K., Vaske J.J., Bright A.D. \& Absher J.D. 2004. Situational influences of acceptable wildland fire management actions. Society and Natural Resources 17, 477-489.

Krupnik I. \& Jolly D. (eds.) 2002. The Earth is faster now: indigenous observations of Arctic environmental change. Fairbanks: Arctic Research Consortium of the United States.

Kumagai Y. 2004. Causal reasoning processes of people affected by wildfire: implications for agency-community interactions and communication strategies. Western Journal of Applied Forestery 19, 184-194.

Larsen P.H., Goldsmith S., Smith O., Wilson M.L., Strzepek K., Chinowski P. \& Saylor B. 2008. Estimating future costs of Alaska public infrastructure at risk from climate change. Global Environmental Change 18, 442-457.

Leichenko R.M. \& O'Brien K.L. 2002. The dynamics of rural vulnerability to global change: the case of southern Africa. Mitigation and Adaptation Strategies for Global Change 7, $1-18$.

Luers A.L. 2005. The surface of vulnerability: an analytical framework for examining environmental change. Global Environmental Change 15, 214-223.

McCaffrey S. 2004. Thinking of wildfire as a natural hazard. Society and Natural Resources 17, 509-516.
McCarthy J.J. \& Martello M.L. 2005. Climate change in the context of multiple stressors and resilience. In C. Symon et al. (eds.): Arctic climate impact assessment. Pp. 945-988. Cambridge: Cambridge University Press.

McGuire A.D., Chapin F.S. III, Walsh J.E. \& Wirth C. 2006. Integrated regional changes in Arctic climate feedbacks: implications for the global climate system. Annual Review Environmental Resources 31, 61-91.

Natcher D.C., Calef M., Huntington O., Trainor S., Huntington H.P., DeWilde L., Rupp S. \& Chapin F.S. III 2007. Factors contributing to the cultural and spatial variability of landscape burning by Native peoples of interior Alaska. Ecology and Society 12(1), article no. 7.

Natcher D.C., Huntington O., Huntington H., Chapin F.S. III, Trainor S.F. \& DeWilde L. 2007. Notions of time and sentience: methodological considerations for Arctic climate change research. Arctic Anthropology 44, 113-126.

National Fire Protection Association 2008. Firewise communities. Accessed on the internet at www.firewise.org on 27 December 2008.

National Science Foundation 2008. Principles for the conduct of research in the Arctic. Accessed on the internet at www.nsf.gov/od/opp/arctic/conduct.jsp on 27 December 2008.

Nelson D.R., Adger W.N. \& Brown K. 2007. Adaptation to environmental change: linkages and a new agenda. Annual Review of Environmental Resources 32, 395-419.

Nelson J.L., Zavaleta E.S. \& Chapin F.S. III 2008. Boreal fire effects on subsistence resources in Alaska and adjacent Canada. Ecosystems 11, 156-171.

O’Brien K., Leichenko R., Kelkar U., Venema H., Aandahl G., Tompkins H., Javed A., Bhadwal S., Barg S., Nygaard L. \& West J. 2004. Mapping vulnerability to multiple stressors: climate change and globalization in India. Global Environmental Change 14, 303-313.

O'Brien K.L., Sygna L. \& Haugen J.E. 2004. Vulnerable or resilient? A multi-scale assessment of climate impacts and vulnerability in Norway. Climatic Change 64, 193-225.

O'Donnell M. 2007. In the ashes, Californians ask how to defeat the Santa Anas. The New York Times, 28 October, section 4, p. 4.

Polsky C., Neff R. \& Yarnal B. 2007. Building comparable global change vulnerability assessments: the vulnerability scoping diagram. Global Environmental Change 17, 472485.

Pyne S.J. 1982. Fire in America. A cultural history of wildland and rural fire. Seattle: University of Washington Press.

Randerson J.T., Liu H., Flanner M., Chambers S.D., Jin Y., Hess P.G., Pfister G., Mack M.C., Treseder K.K., Welp L., Chapin F.S. III, Harden J.W., Goulden M.L., Lyons E., Neff J.C., Schuur E.A.G. \& Zender C. 2006. The impact of Boreal forest fire on climate warming. Science 314 , 1130-1132.

Rupp T.S., Chen X. \& McGuire A.D. 2007. Sensitivity of simulated Boreal fire dynamics to uncertainties in climate drivers. Earth Interactions 11, article no. 3. 
Rupp T.S., Olson M., Adams L.G., Dale B.W., Joly K., Henkelman J., Collings W.B. \& Starfield A.M. 2006. Simulating the influences of various fire regimes on caribou winter habitat. Ecological Applications 16, 1730-1743.

Rupp T.S., Starfield A.M. \& Chapin F.S. III 2000. A frame-based spatially explicit model of subarctic vegetation response to climatic change: comparison with a point model. Landscape Ecology 15, 383-400.

Schroter D., Polsky C. \& Patt A.G. 2005. Assessing vulnerabilities to the effects of global change: an eight step approach. Mitigation and Adaptation Strategies for Global Change 10, 573-596.

Scott C., Brown L.A., Jennings G.B. \& Utermohle C.J. 2001. Community profile database for Access 2000 (version 3.12). Anchorage: Division of Subsistence, Alaska Department of Fish and Game.

Smit B., Burton I., Klein R.J.T. \& Wandel J. 2000. An anatomy of adaptation to climate change and variability. Climatic Change 45, 223-251.

Soja A.J., Tchebackova N.M., French N.H.F., Flannagan M.D., Shugart H.H., Stocks B.J., Sukhinin A.I., Parfenova E.I., Chapin F.S. III \& Stackhouse P.W. 2007. Climate induced Boreal forest change: predictions versus current observations. Global Planetary Change 56, 274-296.

Steelman T.A. \& Kunkel G.F. 2004. Effective community responses to wildfire threats: lessons from New Mexico. Society and Natural Resources 17, 679-699.

Symon C., Arris L. \& Heal B. 2005. Arctic climate impact assessment. Cambridge: Cambridge University Press.

Thomas D.S.G. \& Twyman C. 2005. Equity and justice in climate change adaptation amongst natural-resourcedependent societies. Global Environmental Change 15, 115-124.

Todd S.K. \& Jewkes H.A. 2006. Fire in Alaska: a history of organized fire suppression and management in the last frontier. Fairbanks: University of Alaska.
Trainor S.F. 2006. Emergency fire fighting crew management study. Fairbanks: University of Alaska.

Turner B.L.I., Kasperson R.E., Matson P.A., McCarthy J.J., Corell R.W., Christensen L., Eckley N., Kasperson J.X., Luerse A., Martello M.L., Polsky C., Pulsipher A. \& Schiller A. 2003. A framework for vulnerability analysis in sustainability science. Proceedings of the National Academy of Sciences 100, 8074-8079.

Turner B.L.I., Matson P.A., McCarthy J.J., Corell R.W., Christensen L., Eckley N., Hovelsrud-Broda G.K., Kasperson J.X., Kasperson R.E., Luers A., Martello M.L., Mathiesen S., Naylor R., Polsky C., Pulsipher A., Schiller A., Selin H. \& Tyler N. 2003. Illustrating the coupled human-environment system for vulnerability analysis: three case studies. Proceedings of the National Academy of Sciences 100, 8080-8085.

US Census Bureau 2000. Census 2000. Accessed on the internet at http://factfinder.census.gov on 27 December 2008.

Watt-Cloutier S., Fenge T. \& Crowley P. 2005. Responding to global climate change: the perspective of the Inuit Circumpolar Conference on the Arctic climate impact assessment. Accessed on the internet at www.inuitcircumpolar.com/index.php?ID=267\&Lang=En on 27 December 2008.

Westerling A.L., Hidalgo H.G., Cayan D.R. \& Swetnam T.W. 2006. Warming and earlier spring increase western U.S. forest wildfire activity. Science 313, 940-943.

Wolfe R.J. 2000. Subsistence in Alaska: a year 2000 Update. Juneau: Division of Subsistence, Alaska Department of Fish and Game.

Yin R.K. 2003. Case study research, design and methods. Thousand Oaks, CA: Sage. 